\title{
First record of horned puffin in the North Atlantic and tufted puffin in High Arctic Greenland
}

\author{
Kurt K. Burnham, ${ }^{1}$ Jennifer L. Burnham, ${ }^{2}$ Jeff A. Johnson, ${ }^{3}$ Bridger W. Konkel, ${ }^{1}$ \\ Jack Stephens ${ }^{1}$ \& Hannah Badgett ${ }^{1}$ \\ ${ }^{1}$ High Arctic Institute, Orion, IL, USA \\ ${ }^{2}$ Department of Geography, Augustana College, Rock Island, IL, USA; \\ ${ }^{3}$ Department of Biological Sciences, Institute of Applied Sciences, University of North Texas, Denton, TX, USA
}

\begin{abstract}
An accelerating decrease in summer sea-ice extent in the Arctic Ocean and Canadian Arctic Archipelago (North-west Passage) is predicted to increase the movement of species between the North Pacific and North Atlantic oceans. Here we report observations of two Subarctic North Pacific puffin species in the North Atlantic near the coast of north-west Greenland. We observed a horned puffin (Fratercula corniculata) repeatedly during the summer months of 2002-06 and 2013-19 and a single tufted puffin (F. cirrhata) in 2019. While single tufted puffins have been observed a few times in the North Atlantic, this is the first record of a horned puffin in the North Atlantic, and the first record for both horned and tufted puffins in north-west Greenland. In 2019, both puffin species were observed simultaneously at an Atlantic puffin (F. arctica) colony.
\end{abstract}

\section{Keywords}

Transarctic movement; sea ice; North-west Passage; range shift; Fratercula corniculate; Fratercula cirrhata

\section{Correspondence}

Kurt K. Burnham, High Arctic Institute, 603 10th Avenue, Orion, IL 61273, USA. E-mail: kburnham@higharctic.org

\section{Introduction}

Recent changes in weather and climate have resulted in a northern range expansion for many avian species breeding in temperate zones in the Palearctic and Nearctic (Thomas \& Lennon 1999; Hitch \& Leberg 2007; Virkkala \& Lehikoinen 2017; Dunn \& Møller 2019). In the Arctic, a similar pattern has been observed, with birds extending their northern range limit and species that were once considered rare or vagrant now observed on an annual basis (Gaston \& Woo 2008; Divoky 2011; Brommer et al. 2012; Burnham et al. 2012; Burnham et al. 2014 ; Robinson et al. 2019). More recently, focus has also included the transarctic movement of species, with some hypothesizing that decreasing Arctic sea ice will lead to increased movement among species, including seabirds, between the Pacific and Atlantic oceans (Vermeij \& Roopnarine 2008; Post et al. 2013; McKeon et al. 2016; Clairbaux et al. 2019).

Horned (Fratercula corniculata) and tufted (F. cirrhata) puffins are Subarctic species that breed in the North Pacific from Japan to Alaska to British Columbia, with tufted puffins breeding as far south as California (Gaston \& Jones 1998; Piatt \& Kitaysky 2020a, b; Fig. 1). Over the past 40 years, both species have extended their northern range limit in Alaska and Canada to the Beaufort Sea (Divoky 1982; Divoky et al. 2015; eBird 2020). Horned puffins were first recorded breeding in the Beaufort Sea at Cooper
Island, Alaska, in $1986\left(71.2^{\circ} \mathrm{N}, 155.7^{\circ} \mathrm{W}\right.$; Divoky et al. 2015). The species has subsequently been observed as far east as Herschel Island, Canada $\left(69.6^{\circ} \mathrm{N}, 138.8^{\circ} \mathrm{W}\right.$; eBird 2020) in August 2014, 2016 and 2019, and the MacKenzie Shelf, Canada (single individual; $70.4^{\circ} \mathrm{N}, 130.4^{\circ} \mathrm{W}$; Wong et al. 2014; Gjerdrum \& Fifield 2019) in August 2011 (Fig. 1). Single tufted puffins were observed as far east as Prudhoe Bay, Beaufort Sea $\left(70.3^{\circ} \mathrm{N}, 148.3^{\circ} \mathrm{W}\right)$ in summer 2010 and Herschel Island $\left(69.6^{\circ} \mathrm{N}, 138.9^{\circ} \mathrm{W}\right)$ in summer 2017 and 2019 (eBird 2020; Fig. 1).

Here we report the first observations of both horned and tufted puffins in the High Arctic North Atlantic near the coast of north-west Greenland.

\section{Methods}

The Avanersuaq District in the High Arctic of north-west Greenland is home to the largest populations of breeding seabirds in Greenland (Boertmann et al. 1996; see Burnham et al. 2012 and Burnham et al. 2014 for additional information about the area). For many avian species, this area represents the most northern extent of their breeding ranges (Boertmann et al. 1996). Breeding season surveys have been conducted throughout the Avanersuaq District $\left(75.9^{\circ} \mathrm{N}\right.$ to $\left.77.4^{\circ} \mathrm{N}\right)$ each year starting in 1995 (e.g., Burnham et al. 2014). Surveys were predominately 


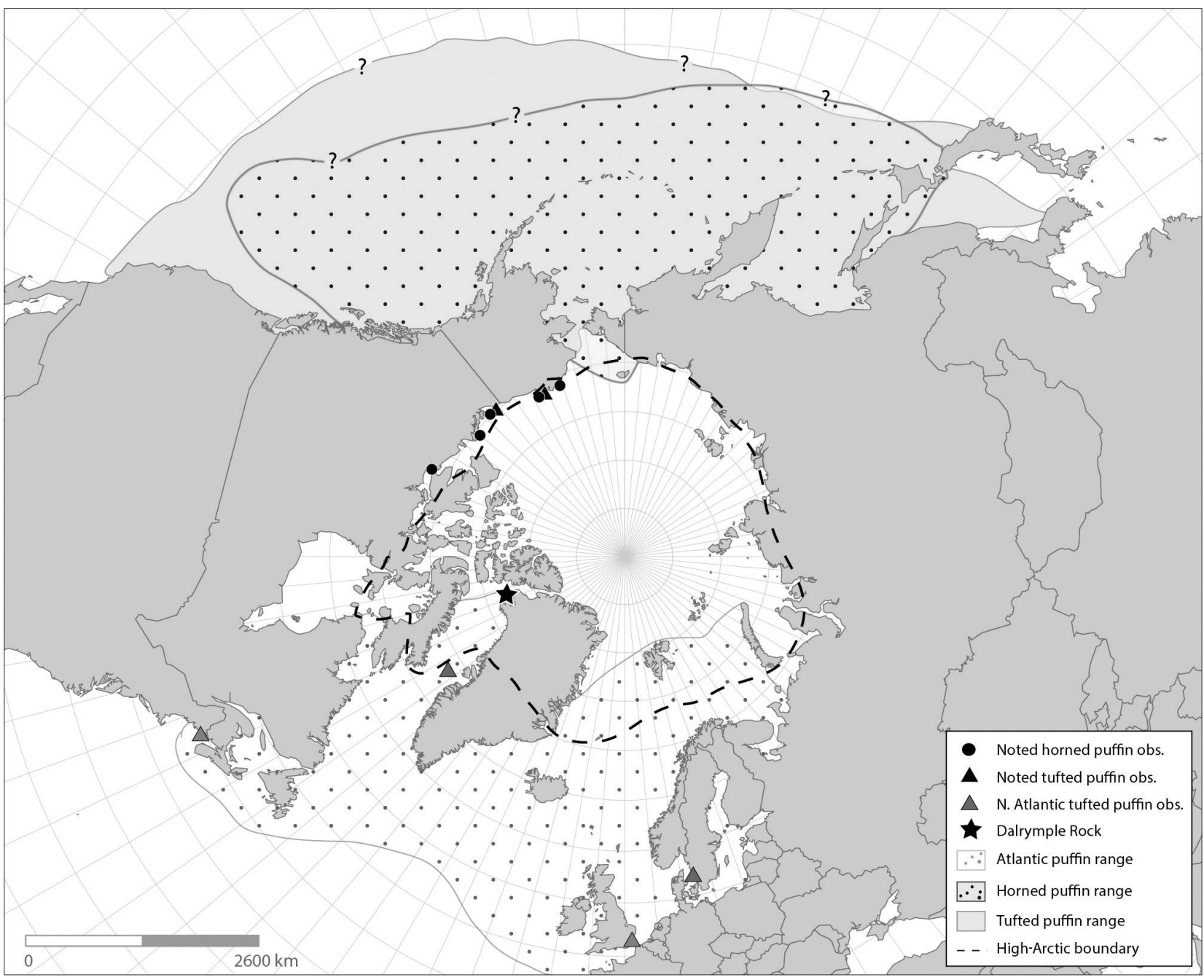

Fig. 1 Horned, tufted and Atlantic puffin breeding and winter ranges and locations of observations noted in the text (ranges based on Nettleship 1996, Gaston \& Jones 1998; see text for references of specific notable observations).

along coastal areas, including islands, and conducted by small open boat $(4.5-8.5 \mathrm{~m})$. Overall area and days of survey varied by year but were conducted between 25 June and 15 August.

\section{Results}

During the periods 2002-06 and 2013-19, a single horned puffin was observed flying, sitting on the water and perched among Atlantic puffins (colony size 15-25 pairs; K. Burnham unpubl. data) on Dalrymple Rock $\left(76.47^{\circ} \mathrm{N}\right.$, $70.22^{\circ} \mathrm{W}$ ) in north-west Greenland (Figs. 1, 2a). While surveys were conducted between 2007 and 2012, only single brief visits were made to Dalrymple Rock, and it is possible a horned puffin was present but not observed. It is therefore unclear whether these records refer to just a single bird. In 2013-19, the horned puffin was frequently observed perched next to a crevice in a small cliff, similar to locations where Atlantic puffins nest at the colony, but no indication of nesting was observed. Additionally, a single tufted puffin was observed in 2019, both flying with Atlantic puffins and on the water within $100 \mathrm{~m}$ of the Atlantic puffin colony (Fig. 2b). No other horned or tufted puffins were seen at other small Atlantic puffin colonies $(<10$ individuals) within the survey area in the Avanersuaq District.

\section{Discussion}

This is the first record of horned puffin in Greenland and the North Atlantic and the most northern record of horned and tufted puffins in the High Arctic. Additionally, 


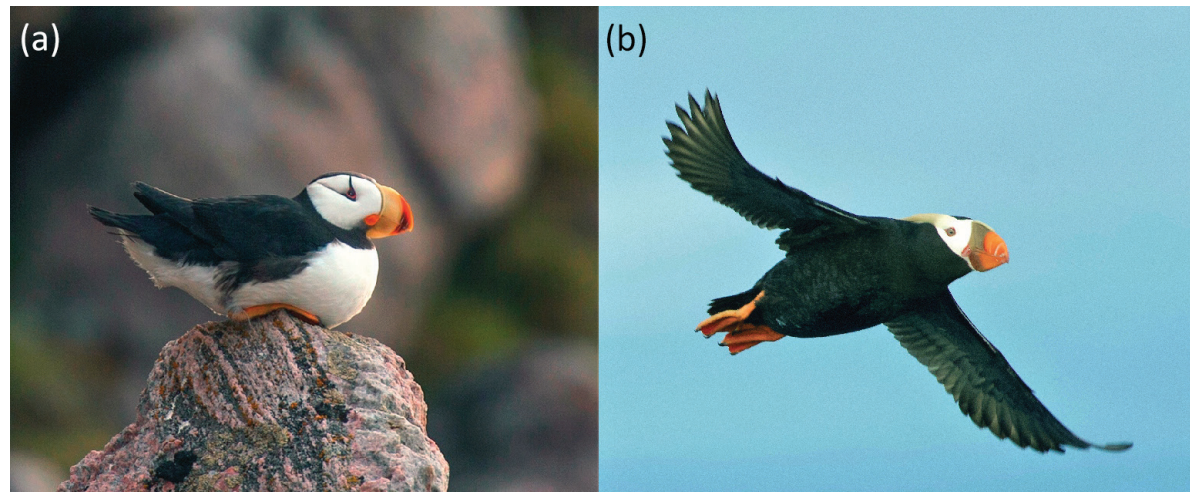

Fig. 2 (a) Horned (photo: Jack Stephens) and (b) tufted (photo: Jeff Johnson) puffins observed at an Atlantic puffin colony on Dalrymple Rock in north-west Greenland.

this is also the first observation of all three Fratercula puffin species at a single colony in the North Atlantic. The only other known occurrence of all three Fratercula species at the same location was in 2008 at Talan Island $\left(59.3^{\circ} \mathrm{N}, 149.1^{\circ} \mathrm{E}\right)$, Sea of Okhotsk, in the Pacific Ocean (Kharitonov 1999).

Records for tufted puffin in the North Atlantic include observations of single individuals in Maine (USA) from mid-June to mid-July 2014 (Bevier 2017), central-west Greenland (about $150 \mathrm{~km}$ off the coast) in mid-August 2009 (Kristensen et al. 2009), England in September 2009 (Wright 2011), Sweden in early June 1994 (Haraldsson 1995) and a single individual shot in Maine during the winter of 1831-32 (Bevier 2017). For horned puffin, the previous easternmost record is for an individual shot at Basil Bay (ca. $68.3^{\circ} \mathrm{N}, 114.7^{\circ} \mathrm{W}$, ca. $48 \mathrm{~km}$ north-west of Kugluktuk, Nunavut) in the Beaufort Sea in August 1973, with recent records from Prudhoe Bay and Herschel Island farther west (Smith 1974; eBird 2020; Fig. 1). This appears to be the first record of a horned puffin in the North Atlantic.

McKeon et al. (2016) detailed the increasing movement of seabird and marine mammal species between the North Atlantic and North Pacific oceans and speculated that this behaviour is likely a result of longer periods without sea ice each year in the Canadian Arctic Archipelago. Similar changes in movement patterns have also been suggested by Vermeij \& Roopnarine (2008) and Clairbaux et al. (2019), with the latter proposing that Arctic seabirds that currently breed in the North Atlantic may find it more energy efficient to become transarctic migrants and then possibly establishing breeding colonies in the North Pacific.

A similar scenario could explain increased sightings of horned and tufted puffin in the North Atlantic and, particularly, north-west Greenland. For example, horned and tufted puffins observed at Liverpool Bay and
Herschel Island, respectively, are at most equidistant, and likely much closer, to wintering areas of Atlantic puffins in the Davis Strait than their own wintering areas in the central North Pacific (Gaston \& Jones 1998; Fayet et al. 2017; Burnham unpubl. data). Although the North-west Passage is mostly free of sea ice in the late summer and fall, during outward migration, the area would be icebound during return migration in the spring, with open water to the north in Davis Strait and Baffin Bay naturally directing individuals to north-west Greenland.

\section{Conclusion}

As horned and tufted puffins continue to expand their range into the Beaufort Sea from the North Pacific and east into northern Nunavut, their occurrence will probably increase in the North Atlantic. If the Arctic Ocean becomes increasingly free of sea ice during the summer, as predicted by climate models (Boé et al. 2009; Notz \& Stroeve 2018), it seems probable that horned and tufted puffins may even colonize and establish breeding populations in the North Atlantic. In the short term, however, it is possible that the three Fratercula species could conceivably hybridize, given their fairly recent common ancestry between 1 and 8.50 million years ago, based on fossil calibrated phylogenetic analyses (Kumar et al. 2017). A similar scenario has already been documented for North Pacific and North Atlantic marine mammals (Kelly et al. 2010). More research is warranted to determine if the observed tufted and horned puffins have reproduced with Atlantic puffins in the surveyed breeding colony.

\section{Disclosure statement}

The authors report no potential conflict of interest. 


\section{Acknowledgements}

The authors thank Calen Offield, Alexandre Paiement, Claire Behnke, Fallon Meyer, Sara Baugh, Jacob Wyco and Bailey Aasen for assistance in the field. They also thank the Greenland Home Rule Government for providing them permission to work in Greenland and the US Air Force for providing access to Thule Air Base. The authors are grateful to Polar Field Services, specifically Jessy Jenkins and Kim Derry, the 109th Air National Guard, the US National Science Foundation, the US Bureau of Land Management, Greenland Contractors and Vectrus for their help with logistics. They extend their special thanks to the residents of Thule Air Base for the long-standing support of all of their research projects in north-west Greenland.

\section{Funding}

Financial support for this project was provided by the Offield Family Foundation, Wolf Creek Charitable Trust, Patagonia, Kim Pelle, the Trout/Jarvis and Cafferty families and many others who have donated to the High Arctic Institute.

\section{References}

Bevier L.R. 2017. Sixth report of the Maine bird record committee. Bird Observer 45, 96-104.

Boé J., Hall A. \& Qu X. 2009. September sea ice cover in the Arctic Ocean projected to vanish by 2100 . Nature Geoscience 2, 341-343, doi: 10.1038/ngeo467.

Boertmann D.A., Mosbech A., Falk K. \& Kampp K. 1996. Seabird colonies in western Greenland $\left(60^{\circ}-79^{\circ} 30^{\prime} \mathrm{N}\right.$. lat). NERI Technical Report 170. Copenhagen: National Environmental Research Institute.

Brommer J.E., Lehikoinen A. \& Valkama J. 2012. The breeding ranges of central European and Arctic bird species move poleward. PLoS One 7, e43648, doi: 10.1371/journal. pone.0043648.

Burnham K.K., Burnham W.A., Newton I., Johnson J.A. \& Gosler A. 2012. The history and range expansion of peregrine falcons in the Thule area, northwest Greenland. Monographs on Greenland 353. Copenhagen: Museum Tusculanum Press.

Burnham K.K., Sinnett D.R., Johnson J.A., Burnham J.L., Baroch J.A. \& Konkel B.W. 2014. New species records and changes in abundance of waterfowl in northwest Greenland. Polar Biology 37, 1289-1300, doi: 10.1007/ s00300-014-1520-z.

Clairbaux M., Fort J., Mathewson P., Porter W., Strøm H. \& Grémillet D. 2019. Climate change could overturn bird migration: transarctic fights and high-latitude residency in a sea ice free Arctic. Scientific Reports 9, article no. 17767, doi: 10.1038/s41598-019-54228-5.
Divoky G. 2011. Black guillemots in a melting Arctic: responding to shifts in prey, competitors, and predators. In R.T. Watson et al. (eds.): Gyrfalcons and ptarmigan in a changing world. Vol. 1. Pp. 125-130. Boise, ID: The Peregrine Fund.

Divoky G.J. 1982. The occurrence and behavior of non-breeding horned puffins at black guillemot colonies in northern Alaska. Wilson Bulletin 94, 356-358.

Divoky G.J., Lukacs P.M. \& Druckenmiller M.L. 2015. Effects of recent decreases in Arctic sea ice on an ice-associated marine bird. Progress in Oceanography 136, 151-161, doi: 10.1016/j.pocean.2015.05.010.

Dunn P.O. \& Møller A.P. 2019. Effects of climate change on birds. Oxford: Oxford University Press.

eBird 2020. eBird: an online database of bird distribution and abundance. Ithaca, NY: Cornell Lab of Ornithology. Accessed on the internet at http://www.ebird.org on 24 January 2020.

Fayet A.L., Freeman R., Anker-Nilssen T., Diamond A., Erikstad K.E., Fifield D., Fitzsimmons M.G., Hansen E.S., Harris M.P., Jessopp M., Kouwenberg A.L., Kress S., Mowat S., Perins C.M., Petersen A., Petersen I.K., Rejertsen T.K., Robertson G.J., Shannon P., Sigurðsson I.A., Shoji A., Wanless S. \& Guilford T. 2017. Ocean-wide drivers of migration strategies and their influence on population breeding performance in a declining seabird. Current Biology 27, 3871-3878, doi: 10.1016/j.cub.2017.11.009.

Gaston A.J. \& Jones I.L. 1998. The auks. Oxford: Oxford University Press.

Gaston A.J. \& Woo K. 2008. Razorbills (Alca torda) follow Subarctic prey into the Canadian Arctic: colonization results from climate change? Auk 125, 939-942, doi: 10.1525/auk.2008.07195.

Gjerdrum C. \& Fifield D. 2019. CWS-EC Eastern Canada Seabirds at Sea (ECSAS). Version 5 (2019-Feb). Bedford Institute of Oceanography, Dartmouth, NS, Canada. Ocean Biogeographic Information System, Canada Digital Collections. Accessed on the internet at http://www.iobis. org/ on 8 April 2020.

Haraldsson M. 1995. The tufted puffin Fratercula cirrhata in the mouth of the Lagan River 1 and 8 June 1994. Var Fågelvärld (Supplement) 22, 152-153.

Hitch A.T. \& Leberg P.L. 2007. Breeding distributions of North American bird species moving north as a result of climate change. Conservation Biology 21, 534-539, doi: 10.1111/j.1523-1739.2006.00609.x.

Kelly B., Whiteley A. \& Tallmon D. 2010. The Arctic melting pot. Nature 568, 891, doi.org/10.1038/468891a.

Kharitonov S.P. 1999. The first record of the Atlantic puffin (Fratercula arctica) in the Pacific, and routes of alcid vagrancy between the Atlantic and Pacific oceans. Bulletin of the North-Eastern Research Center of FEB RAS 3, 105-107.

Kristensen A.B., Frich A.S., Ortvad T.E. \& Schwalbe M. 2009. Sjældne fugle i Danmark og Grønland i 2009. (Rare birds in Denmark and Greenland in 2009. With English summary.) In J. Staarup \& P. Lange (eds.): Fugleåret 2009. (Bird yearbook 2009.) Pp. 131-151. Copenhagen: Danish Ornithological Society. 
Kumar S., Stecher G., Suleski M. \& Hedges S.B. 2017. TimeTree: a resource for timelines, timetrees, and divergence times. Molecular Biology and Evolution 34, 1812-1819, doi: 10.1093/molbev/msxl 16 .

McKeon C.S., Weber M.X., Alter S.E., Seavy N.E., Crandall E.D., Barshis, D.J., Fechter-Leggett E.D. \& Oleson K.L.L. 2016. Melting barriers to faunal exchange across ocean basins. Global Change Biology 22, 465-473, doi: 10.1111/ gcb.13116.

Nettleship D.N. 1996. Family Alcidae (auks). In J. del Hoyo et al. (eds.): Handbook of the birds of the world. Vol. 3. Pp. 678-722. Barcelona: Lynx Edicions.

Notz D. \& Stroeve J. 2018. The trajectory towards a seasonally ice-free Arctic Ocean. Current Climate Change Reports 4, 407-416, doi: 10.1007/s40641-018-0113-2.

Piatt J.F. \& Kitaysky A.S. 2020a. Horned puffin (Fratercula corniculata), version 1.0. In S.M. Billerman (ed.): Birds of the world. Ithaca, NY: Cornell Lab of Ornithology. Accessed on the internet at https://doi.org/10.2173/bow.horpuf.01 on 27 April 2020.

Piatt J.F. \& Kitaysky A.S. 2020b. Tufted puffin (Fratercula cirrhata), version 1.0. In S.M. Billerman (ed.): Birds of the world. Ithaca, NY: Cornell Lab of Ornithology. Accessed on the internet at https://doi.org/10.2173/bow.tufpuf.01 on 27 April 2020.
Post E., Bhatt U.S., Bitz C.M., Brodie J.F., Fulton T.L., Hebblewhite M., Kerby J., Kutz S.J., Stirling I. \& Walker D.A. 2013. Ecological consequences of sea-ice decline. Science 341, 519-524, doi: 10.1126/science.1235225.

Robinson B.W., Johnson A.S., Lovette I.J. \& Romano M.D. 2019. Potential northward expansion of the breeding range of red-legged kittiwake Rissa brevirostris. Marine Ornithology 47, 229-234.

Smith T.G. 1974. A horned puffin, Fratercula coniculata, near Coppermine, Northwest Territories. Canadian Field Naturalist 88,353 .

Thomas C.D. \& Lennon J.J. 1999. Birds extend their ranges northwards. Nature 399, 213, doi: 10.1038/20335.

Vermeij G.J. \& Roopnarine P.D. 2008. The coming Arctic invasion. Science 321, 780-781, doi: 10.1126/science.1160852.

Virkkala R. \& Lehikoinen A. 2017. Birds on the move in the face of climate change: high species turnover in northern Europe. Ecology and Evolution 7, 8201-8209, doi: 10.1002/ece3.3328.

Wong S.N.P., Gjerdrum C., Morgan K.H. \& Mallory M.L. 2014. Hotspots in cold seas: the composition, distribution, and abundance of marine birds in the North American Arctic. Journal of Geophysical Research-Oceans 119, 16941705, doi: 10.1002/2013JC009198.

Wright M. 2011 . Tufted puffin in Kent: new to Britain. British Birds 104, 261-265. 